\title{
Effect of Herbal Feed Supplementation Shatavari (Asparagus racemosus) on Milk Yield and Post-Partum Estrus in Lactating Sahiwal Crossbred Cows
}

\author{
Hitesh Muwal $^{1 *}$, D. C. Rai ${ }^{1}$, Vinod Bhateshwar ${ }^{1}$, Dwarki Lal ${ }^{1}$ and Hanuman Lal Nehra ${ }^{2}$ \\ ${ }^{1}$ Department of Animal Husbandry \& Dairying, Banaras Hindu University, \\ Varanasi (U.P.) India \\ ${ }^{2}$ Department of Livestock Production Management, Sri Karan Narendra \\ Agriculture University, Jobner, Rajasthan India \\ *Corresponding author
}

Keywords

Shatavari, Sahwail, Crossbred, Milk yield and PostPartum estrus

Article Info

Accepted:

20 January 2020

Available Online:

10 February 2020

\section{A B S T R A C T}

The present investigation was conducted to assess the effect of herbal feed supplementation Shatavari (Asparagus racemosus) on milk yield and PostPartum estrus in lactating Sahiwal crossbred cows during summer season on twenty lactating Sahiwal crossbred (Holstein Friesian x Sahiwal) cows in early stage of lactation were selected for the experiment between 1 February 2019 to 31 May 2019 (120 days Post-Partum). All the cows were randomly divided into two groups $\mathrm{T}_{1}$ (control) and $\mathrm{T}_{2}$ (Treatment) of 10 in each group. The treatment group was provided Shatavari root powder @ 50 $\mathrm{g} / \mathrm{head} /$ day for 90 days Post-Partum. Data related to Milk production take fortnightly interval. The average fortnightly milk yield of 90 days lactation trail was $9.88 \pm 0.15$ and $10.87 \pm 0.41 \mathrm{~kg} / \mathrm{d}$ in $\mathrm{T}_{1}$ (control) and $\mathrm{T}_{2}$ groups respectively and was significantly $(\mathrm{P}<0.05)$ higher in $\mathrm{T}_{2}$ than the $\mathrm{T}_{1}$ (control). Mean of first Post-Partum estrus and service period was $77.50 \pm 2.50$ and $52.83 \pm 1.27$ days, and $112.50 \pm 2.50$ and $90.16 \pm 1.44$ days respectively, in the $T_{1}$ (control) and $T_{2}$ group was significantly reduced $(\mathrm{P}<0.05)$.

\section{Introduction}

India, a developing country is a land of villages and more than $70 \%$ of the human population still depends upon agriculture and livestock sector for their livelihood. Livestock sector plays a critical role in the welfare of
India's rural population. India is the highest milk producer in the world and with increase in number of milch animals (in-milk and dry) in cows and buffaloes have increased from 111.09 million to 118.59 million, an increase of $6.75 \%$ (19 ${ }^{\text {th }}$ Livestock census, 2012). The growth is on account of both improvements in 
productivity and shift in priorities towards buffalo and crossbred cattle. Yet, the productivity is low compared to the potential and world average. Out of the total 190.90 million cattle present in India, 39.73 million are crossbred cattle (19th Livestock census, 2012). Contribution of crossbred cattle to the $44 \%$ of the total cattle milk production was 16\% (Singh, et al., 2008) 6.75 vs. 1.98 lit/day (Hegde, 2010). They are more prone to environmental stress, diseases and infertility and sub-fertility due to sub-estrous, anoestrus, repeat breeding and longer Post-Partum interval (PPI) days open and service per conception.

Sahiwal cow a zebu breed of cattle has all the desirable characteristics for an efficient dairy animal in addition to high milk yields viz. heat tolerance, tick and parasite resistance, ease of calving, bloat tolerant, good temperament and disease resistance which are perfectly suited for arid and tropical climatic condition. There is a need for agents to alleviate environmental stressors for improving productivity in this breed of cattle. Sahiwal is the heaviest milker of all zebu breeds and display a well-developed udder.

The ancient history of India is very rich in herbal medicine. Ayurveda, one of the oldest surviving systems of health care in the world is totally based on herbs. There are several herbs which have been described in the Ayurveda to improve the general well beings, milk production and reproduction of both human and animals. Among them, Shatavari (Asparagus racemosus) needs a special mention.

Ayurveda described that Shatavari overcomes all reproduction related complications and improves overall physiological system so called pillars of health including digestion, energy metabolism, immune and reproductive system. Shatavari is a creeper grown in all the tropical countries which is an important medicinal plant of tropical and subtropical India since prehistoric times. The genus Asparagus includes about 300 species around the world.

Out of these, 22 species of Asparagus are found in India; In Sanskrit, the meaning of Shatavari is described as "able to have one hundred husbands" and in Ayurveda this amazing herb is known as the "queen of herbs". In Ayurveda, Shatavari has been described as absolutely safe for long term use, even during pregnancy and lactation. So it is recommended during last and first trimester of pregnancy to restore the mother's energy, boost the immunity of both mother and foetus, promote quality breast milk and promote digestion (Maasaanumaasi kapathya, Garbhini Paricharya, Prasuthi Tantra, Ayurveda).

\section{Materials and Methods}

\section{Place of work}

The present study was conducted on lactating Sahiwal crossbred cows reared at Gaushala Dairy Farm, Department of Animal Husbandry and Dairying, Institute of Agricultural Sciences, Banaras Hindu University, Varanasi, Uttar Pradesh between 1 February 2019 to 31 May 2019 (120 days of Post-Partum) during summer season.

\section{Selection of experimental animals and treatments}

Twenty lactating Sahiwal crossbred (Holstein Friesian $x$ Sahiwal) cows in early stage of lactation were selected for the experiment. At the end of acclimatisation period all the cows were randomly divided into two groups $\mathrm{T}_{1}$ (control) and $\mathrm{T}_{2}$ (Treatment) of 10 in each group on basis of nearest in their body weight, number of lactation and milk yield of average per day. 


\section{Housing and management of experimental animals}

Similar housing and managemental facilities were provided to all the groups. The experimental crossbred cows were kept individually tied day and night during experimental period in cattle shed. The animals were offered individual feeding. The floor area was paved with cement concrete duly corrugated to prevent the animal from slipping. The animals were washed daily before milking at day time when the sun light was clear. The shed was cleaned daily early in the morning. All crossbred cows were dewormed with suitable anthelmentics for removing parasitic eggs before the start of actual experiment.

\section{Feeding of experimental animals}

\section{Milk yield}

During the month of February 2019 after calving, for individual lactating cow milk yield was measured at 15 days intervals (i.e., on $0,15,30,45,60,75$, and 90) using a digital balance and milking was done by hand milking. Before every milking, lactating cows were cleaned and rinse properly. The milk yield was recorded in litre. Hand milking was performed on two occasions (morning at 5:00 am and afternoon at 4:00 pm). After milking the milk was collected in milk can after screening through muslin cloth.

\section{Post-Partum estrus estimation}

After parturition all experimental animals were observed regularly for first symptom of heat during both morning and evening. The interval from parturition to first symptom of heat was recorded to determine days from calving to first heat. Estrus detection was being carried out by teaser bull which was used twice a day (morning and evening) for identifying cows in estrus. Teaser bull was used after one month of parturition. Estrus was also detected by visualizing various estrus behaviour signs. The estrus signs like bellowing, frequent micturition, mucus discharge, wagging of tail and stand to be mounted were noted in cows induced to estrus.

\section{Statistical Analysis}

Data related to milk yield and Post-Partum estrus were statistically analyzed using the one-way analysis of variance (SPSS version 21.0) for completely randomized design. All statement of significant differences was based on the 0.05 probability level. Significant differences among treatment, within the experiment, were analyzed using the SPSS statistical software program.

\section{Results and Discussion}

\section{Milk yield}

The average fortnightly milk yield of 90 days lactation trial was (Table 2) $9.88 \pm 0.15$ and $10.87 \pm 0.41 \mathrm{~kg} / \mathrm{d}$ in $\mathrm{T}_{1}$ (control) and $\mathrm{T}_{2}$ groups respectively and it was found that milk yield increased significantly $(\mathrm{P}<0.05)$ higher in $\mathrm{T}_{2}$ than the $\mathrm{T}_{1}$ (control). The milk yield ranged between $9.41 \pm 0.35$ to $10.54 \pm 0.26$ and $9.62 \pm 0.44$ to $12.39 \pm 0.19 \mathrm{~kg} / \mathrm{d}$ in $\mathrm{T}_{1}$ (control) and $\mathrm{T}_{2}$ groups respectively in different fortnights. Statistical analysis of data found positively significant variation between the groups. The similar result also found by Tanwar et al., (2008) evaluated significant improvement in overall milk yield were increased $1.06 \pm 0.17 \mathrm{~kg}(11.47 \%)$ daily and average milk yield in buffaloes and cows were increased $0.8 \pm 0.34 \mathrm{~kg}(9.0 \%), 1.32 \pm 0.15$ $\mathrm{kg}(12.72 \%)$ respectively as compared to their previous production. Shatavari significantly $(\mathrm{P}<0.05)$ increased milk production during supplementation by 20 percent in treatment 
group $(23.40 \mathrm{~kg})$ over control group (19.50 kg) (Santosh, 2009). Sharma (2010) also found that polyherbal supplementation containing Shatavari @ $200 \mathrm{mg} / \mathrm{kg} \mathrm{BW}$, significantly increased the milk yield by $12.24, \quad 15.01$ and $10.50 \%$ during supplementation, residual and post residual periods, respectively. The milk production was increased $0.60 \pm 0.27 \mathrm{~kg}(9.67 \%)$ daily respectively as compared to their previous production supplementation of $50 \mathrm{gm}$ powder of shatavari roots in concentrates (Jingar et al., 2018).

Table.1 Distribution of experimental lactating Sahiwal crossbred cows

\begin{tabular}{|c|c|c|c|c|}
\hline Treatments & $\begin{array}{c}\text { Tag No. of } \\
\text { Animal }\end{array}$ & $\begin{array}{l}\text { Body weight } \\
\text { (in kg) }\end{array}$ & Lactation No. & $\begin{array}{l}\text { Milk production } \\
\text { (in litres/day) }\end{array}$ \\
\hline \multirow[t]{10}{*}{$\mathbf{T}_{1}$} & 604 & 462.48 & 02 & 9.20 \\
\hline & 930 & 428.85 & 03 & 10.12 \\
\hline & 494 & 350.43 & 05 & 8.20 \\
\hline & 801 & 452.80 & 07 & 9.00 \\
\hline & 934 & 392.39 & 01 & 8.00 \\
\hline & 792 & 345.12 & 03 & 10.00 \\
\hline & 640 & 472.82 & 08 & 10.25 \\
\hline & 727 & 360.55 & 01 & 9.50 \\
\hline & 935 & 465.62 & 06 & 10.35 \\
\hline & 885 & 378.04 & 04 & 9.60 \\
\hline Average & - & $410.91 \pm 16.16$ & - & $9.41 \pm 0.35$ \\
\hline \multirow[t]{10}{*}{$\mathbf{T}_{2}$} & 768 & 482.40 & 06 & 9.20 \\
\hline & 637 & 465.21 & 01 & 10.16 \\
\hline & 564 & 362.05 & 09 & 8.75 \\
\hline & 878 & 452.70 & 03 & 9.93 \\
\hline & 806 & 349.44 & 05 & 10.32 \\
\hline & 789 & 455.38 & 02 & 9.40 \\
\hline & 766 & 360.11 & 07 & 10.82 \\
\hline & 609 & 341.28 & 05 & 8.00 \\
\hline & 786 & 450.12 & 08 & 10.58 \\
\hline & 894 & 381.58 & 04 & 9.18 \\
\hline Average & - & $410.02 \pm 17.56$ & - & $9.62 \pm 0.44$ \\
\hline
\end{tabular}


Table.1(A) Feeding schedule of lactating Sahiwal crossbred cows

\begin{tabular}{|c|c|c|}
\hline S. No. & Feed and fodders & Quantity of feed and fodders \\
\hline $\mathbf{1 .}$ & Wheat straw & $8.0 \mathrm{~kg}$ offered and fed $\mathrm{ad} \mathrm{lib}$. \\
\hline $\mathbf{2 .}$ & Concentrate mixture & $\begin{array}{r}2.0 \mathrm{~kg} \text { for maintenance ration/animal and @ } 1.0 \mathrm{~kg} / 2.5 \mathrm{litre} \\
\text { milk yield for production ration }\end{array}$ \\
\hline $\mathbf{3 .}$ & Green fodder (Lucerne) & $5.0 \mathrm{~kg} / \mathrm{head} / \mathrm{day}$ \\
\hline $\mathbf{4 .}$ & Shatavari root powder & @ $50 \mathrm{~g} / \mathrm{head} /$ day was offered \\
\hline
\end{tabular}

Table.2 Fortnightly milk yield (lit.) supplementation with or without Shatavari root powder during the experiment

\begin{tabular}{|c|c|c|}
\hline Days & \multicolumn{2}{|c|}{ Treatments } \\
\hline & $\mathbf{T}_{\mathbf{1}}$ (Control) & $\mathbf{T}_{\mathbf{2}}$ \\
\hline $\mathbf{0}$ & $9.41 \pm 0.35$ & $9.62 \pm 0.44$ \\
\hline $\mathbf{1 5}$ & $9.53 \pm 0.56$ & $9.78 \pm 0.58$ \\
\hline $\mathbf{3 0}$ & $9.65 \pm 0.48$ & $10.15 \pm 0.24$ \\
\hline $\mathbf{4 5}$ & $9.80 \pm 0.26$ & $10.73 \pm 0.15$ \\
\hline $\mathbf{6 0}$ & $10.00 \pm 0.20$ & $11.54 \pm 0.10$ \\
\hline $\mathbf{7 5}$ & $10.28 \pm 0.11$ & $11.92 \pm 0.23$ \\
\hline $\mathbf{9 0}$ & $10.54 \pm 0.26$ & $12.39 \pm 0.19$ \\
\hline Overall mean & $\mathbf{9 . 8 8} \pm \mathbf{0 . 1 5}$ & $\mathbf{1 0 . 8 7 \pm 0 . 4 1}$ \\
\hline
\end{tabular}

Table.3 Effect of Shatavari root powder supplementation on reproductive performance in lactating Sahiwal crossbred cows

\begin{tabular}{|c|c|c|}
\hline Reproductive parameter & \multicolumn{2}{|c|}{ Treatments } \\
\hline & $\mathbf{T}_{\mathbf{1}}$ (Control) & $\mathbf{T}_{\mathbf{2}}$ \\
\hline Number of animals & 10 & 10 \\
\hline First Post-Partum estrus (days) & $77.50 \pm 2.50$ & $52.83 \pm 1.27$ \\
\hline Service period (days) & $112.50 \pm 2.50$ & $90.16 \pm 1.44$ \\
\hline Total conceived & 2 & 6 \\
\hline Conception rate (\%) & 20 & 60 \\
\hline Nature of discharge & Crystal clear & $\begin{array}{c}\text { Crystal clear, } \\
\text { Transparent }\end{array}$ \\
\hline
\end{tabular}




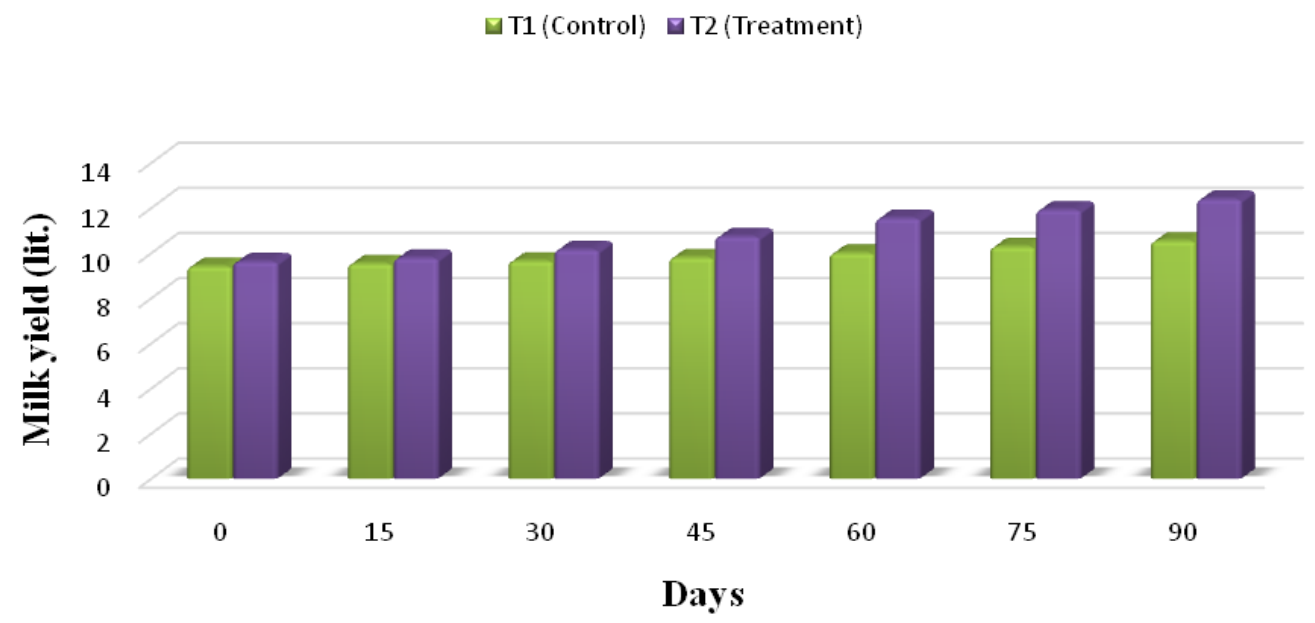

Fig.1 Milk yield changes of experimental cows during feeding experiment

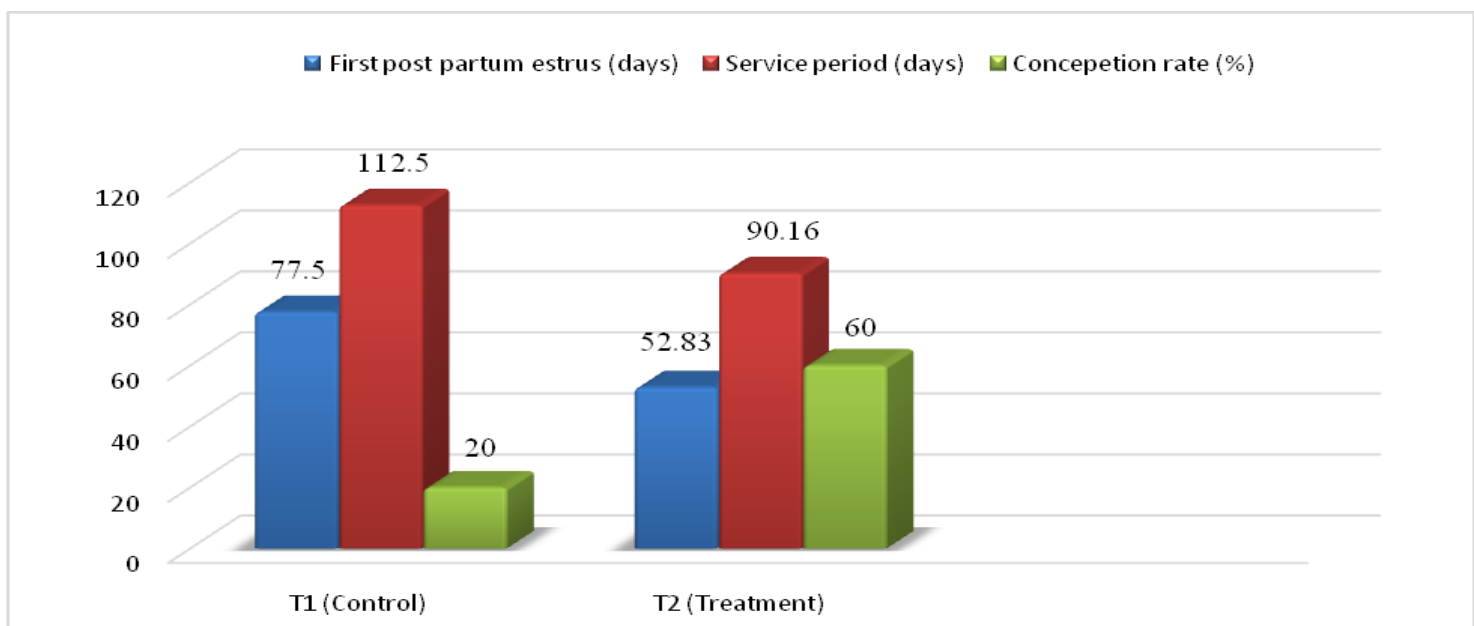

Fig.2 Effect of Shatavari root powder supplementation on reproductive performance in lactating Sahiwal crossbred cows

\section{Post-partum estrus}

Mean of first Post-Partum estrus (days to first postpartum) was (Table 3) $77.50 \pm 2.50$ and $52.83 \pm 1.27$ in the $\mathrm{T}_{1}$ (control) and $\mathrm{T}_{2}$ groups respectively. The first Post-Partum estrus days was significantly less in $\mathrm{T}_{2}$ than $\mathrm{T}_{1}$ (control). However, statistical analysis showed that there was significantly $(\mathrm{P}>0.05)$ differences among the $\mathrm{T}_{1}$ (control) and $\mathrm{T}_{2}$ groups.

The means of service period (days) in $T_{1}$ (control) and $\mathrm{T}_{2}$ was $112.50 \pm 2.50$ and $90.16 \pm 1.44$, respectively (Table 3 ). The statistical analysis indicated that the service period in $\mathrm{T}_{2}$ was significantly reduced $(\mathrm{P}<0.05)$ than that of $\mathrm{T}_{1}$ (control) group, which might be due to stage of lactation and initiation of supplementation of Asparagus racemosus.

The present findings were in agreement with (Santosh, 2009) reported the effect of supplementation of Asparagus racemosus root powder weight at postpartum (up to 90 days), significantly $(\mathrm{P}<0.05)$ lowered service period, service per conception and but significantly $(\mathrm{P}<0.05)$ increased conception rate in treatment group than control. 
Reproduction performance as indicated by lesser days to postpartum oestrus, first service, number of services/conception, lower service period and higher conception rate in polyherbal supplementation fed groups was better than control (Sharma, 2010). In the similar way the effect of Shatavari root powder found significant $(\mathrm{P}<0.05)$ reduction in service period and service/conception in experimental group than control group (Kumar et al., 2014, Singh et al., 2014).

On the basis of the present investigation, it may be concluded that supplementation of Shatavari root powder @ $50 \mathrm{~g} / \mathrm{head} /$ day from calving up to 90 days Post-Partum respectively, increased milk yield and reproductive performance (first Post-Partum estrus interval, service period and service per conception) in lactating Sahiwal crossbred cows. These results are only indicative and require further experimentation to arrive at some more consistent conclusion.

\section{References}

Hegde, N. G. (2010). Livestock development for sustainable livelihood of small farmer's souvenir of the 39th annual general meeting and 48th national symposium on energising rural India. A challenge to livestock industry. Compound livestock feed manufactures association of India (CLFMA), Manesar, Haryana. August 26: 50-63.

Jingar, S. C., Sharma, R., Lawania, P., Kumar, A., Bugaliya, H. and Meena, S. M. (2018). Effect of Shatavari (Asparagus recemosus) on milk production in lactating buffaloes. Int. J. Curr. Microbiol. App. Sci, 7 (9): 36103612 .

Kumar, S., Mehla, R. K. and Singh, M. (2014). Effect of Shatavari (Asparagus racemosus) on milk production and Immune- modulation in Karan Fries crossbred cows. Indian Journal of Traditional Knowledge, 13 (2): 404408.

Livestock Census 2012, Department of Animal Husbandry, Dairying and Fisheries. 19th livestock Census, Govt. of India.

Santosh, K. (2009). Effect of herbal feed supplement Shatavari (Asparagus racemosus) on productive performance of crossbred cows. P. hD. thesis submitted to National Dairy Research Institute (Deemed University), Karnal, Haryana, India.

Sharma, A. (2010). Influence of polyherbal immunomodulator supplementation on production performance and milk quality of Karanfries cows. P. hD. thesis, National Dairy Research Institute, Karnal, Haryana, India.

Singh Jamara, M., Mehla, R. K., Singh, M., Ali, M. M. and Chouhan, N. (2014). Effect of the fed Shatavari (Asparagus racemosus) on body weight and puberty of Sahiwal heifers. International Journal of Agricultural Science and Veterinary Medicine, 2 (1).

Singh, V. K., Singh, P., Verma, A. K. and Mehra, U. R. (2008). On farm assessment of nutritional status of lactating cattle and buffaloes in urban, periurban and rural areas of middle gangetic plains. Livestock Research for Rural Development, 20 (8): Downloaded from: www.lrrd.org/lrrd20/8/singh20130.htm.

Tanwar, P. S., Rathore, S. S. and Kumar, Y. (2008). Effect of Shatavari (Asparagus recemosus) on milk production in dairy animals. Indian J. Anim. Res, 42 (3): 232-233. 


\section{How to cite this article:}

Hitesh Muwal, D. C. Rai, Vinod Bhateshwar, Dwarki Lal and Hanuman Lal Nehra. 2020. Effect of Herbal Feed Supplementation Shatavari (Asparagus racemosus) on Milk Yield and Post-Partum Estrus in Lactating Sahiwal Crossbred Cows. Int.J.Curr.Microbiol.App.Sci. 9(02): 2921-2928. doi: https://doi.org/10.20546/ijcmas.2020.902.332 